\title{
COVID-19 Vaccine Candidates - Current Status
}

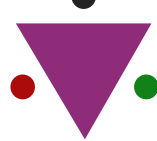

IJCRR

Section: Healthcare

Sci. Journal Impact

Factor: 6.1 (2018)

ICV: 90.90 (2018)

(c) (7) (8)

Copyright@IJCRR

\section{Karthik V' ${ }^{1}$ Geetha R.V. ${ }^{2}$, Leslie Rani S. ${ }^{3}$}

'Saveetha Dental College and Hospital, Saveetha Institute of Medical and Technical Sciences, Saveetha University, Chennai, Tamil Nadu, India; ${ }^{2}$ Associate Professor, Department of Microbiology, Saveetha Dental College and Hospitals, Saveetha Institute of Medical and Technical Sciences, Saveetha University, Chennai, Tamil Nadu, India; ${ }^{3}$ Lecturer, Department of General Pathology, Saveetha Dental College and Hospital, Saveetha Institute of Medical and Technical Sciences, Saveetha University, Chennai, Tamil Nadu, India.

\section{ABSTRACT}

Introduction: Coronavirus belongs to the RNA group of viruses. Coronaviruses, first discovered in domestic poultry in the 1930s, is known to infect mostly the birds and mammals. A few strains can cause mild infection in the upper respiratory tract, like the common cold, but also more serious lower respiratory tract infections including pneumonia primarily in infants, older people, and the immunocompromised. This caused an impact on the current issue of the outbreak of COVID-19. COVID-19 vaccine is a theoretical vaccine against coronavirus 2019. Scientists are seriously working to produce effective vaccines that are under clinical trial. The outbreak of novel coronavirus caused by the SARS-CoV-2 has spread rapidly around the globe. Considering the potential threat of a pandemic, scientists, and physicians have been trying to develop a vaccine to eradicate the virus.

Aim: The main aim of the review is to establish the current scenario on the development of the COVID-19 vaccine.

Materials and Method: Around 50 articles from PubMed, Google Scholar, etc. were collected using keywords, analyzed, and review has been written.

Conclusion: There is an increasing urge in the production of a vaccine for COVID infection. Many countries like the US, Russia, Australia, India, and other countries have successfully completed Phase-I and Phase-II trials and entered the human trail. In India, the vaccine produced by the Serum Institute of India the "Covi shield" and the one produced Bharat Biotech Ltd., the "Covaxin" have successfully entered the human trail. The Food and Drug Administration (FDA) has said that it was up to the vaccine developers to make the application for emergency use authorization, and if the application was found to be "appropriate", it may consider granting approval.

Key Words: Coronavirus, Vaccine, Prophylaxis, Development, SARS-CoV-2, COVID-19

\section{INTRODUCTION}

Coronavirus belongs to the RNA family. COVID-19 was discovered recently in China in December, $2019^{1}$. More than thousands of patients were admitted to the hospital with symptoms like fever, cough, shortness of breath and throat pain, etc ${ }^{2}$. The patients were scanned by computed tomography which showed various opacities in the initial diagnosis; later the pathogen was identified as "CORONAVIRUS" ${ }^{3}$. Coronavirus causes disease in mammals, birds, etc. The most common symptoms were common cold ${ }^{4}$. This common cold then became lethal to life as it was in combination with SARS, MERS, and COVID-19 ${ }^{5}$. The most pathogenic structure of the virus was the glycoprotein spikes which were presented in the capsule of the virus ${ }^{6}$. It was transmitted by contact with an infected person ${ }^{7}$. It caused multiple organ failure which includes pneumonia, fever, cough, and also found to affect kidney, heart, and GIT ${ }^{8}$. The coronavirus became more contagious as it was able to stay on any surface for a minimum of 2 hours ${ }^{9}$. The mortality and the morbidity rate increases, scientists are drilling down to find the mechanism of the virus, to discover a vaccine to eradicate this disease.

Vaccines are the substance used to activate the immune response of a person by evoking the production of antibodies ${ }^{11}$. There are different techniques for the synthesis of COVID vaccines. The mechanism of the vaccine is to evoke antibodies artificially. The traditional way of producing vaccines is by culturing the virus in a medium and injecting them into a

\section{Corresponding Author:}

Dr. R.V. Geetha, Department of Microbiology, Saveetha Dental College and Hospitals, Saveetha Institute of Medical and Technical Sciences Saveetha University, Chennai, Tamil Nadu, India; Phone: 9710456203; Email: rvgeetha2015@gmail.com

ISSN: 2231-2196 (Print)

Received: 26.08 .2020
ISSN: 0975-5241 (Online)

Revised: 22.09 .2020
Accepted: 18.10 .2020
Published: 03.11 .2020 
trial object in inactivated form ${ }^{12}$. Due to the increasing threat of the pandemic, scientists and physicians have been racing to understand the pathophysiology virus, the disease to uncover the possible treatment regions, and discover effective vaccines ${ }^{13}$. The vaccine mainly aims at antiviral strategies involving small molecule and biological targeting complex molecular interaction involved in coronavirus infection ${ }^{14}$. The need to rapidly develop a vaccine against SARS-COV2 comes at a the time of explosion in basic scientific understanding including in areas such as genomics and structural biology that is supporting a new area in vaccine development ${ }^{15}$. The main drawback is that the synthesis of vaccines requires a minimum of one year of trial, since Phase- 3 of vaccine preparation is the longest ${ }^{16}$. So this study analyses the challenges faced by the scientists in the preparation for a vaccine and its current status against COVID-19 ${ }^{17}$.

\section{COVID-19 vaccine development - Current status}

Many countries are on the verge of developing potential vaccines to stop the spread of Covid-19. Scientists from London's Imperial College are working to bring a low-cost vaccine to the world early next year. They are in the process of developing a coronavirus vaccine based on self-amplifying RNA technology. The vaccine is now due to enter phase one and two human clinical trials with 300 people. There are nearly 224 candidate vaccines in development globally, according to the data collected by the Coalition for Epidemic Preparedness Innovations (CEP).

\section{MERS vaccine development}

Scientists are working on finding the sequence of SARS and MERS n-CoV for vaccine synthesis but still the sequence remains unclear ${ }^{18}$. In the in silico method, the prediction of epitopes was carried, this showed MEIC allele sequence of spike glycoprotein ${ }^{19}$. But then later it was found it showed various nucleation alany bioinformatics tools were used to identify the epitopes, which included IEDB analysis to find the epitope mapping ${ }^{20}$. Glycoprotein spike protein sequence was analyzed among which KRSFIELDLC FNKV sequence which showed a notable relation between SARS and COVID-19. The other drawback is that, for the development of vaccines, more time is needed for proper analysis of its effects and use. The development of vaccines is a complex and time-consuming process, which differs from the development of conventional processes. Normally a time required for the development of a vaccine is $12-15$ years ${ }^{21,22}$. If a person comes into contact with a native pathogen, the immune system will already have the necessary antibody ready and will multiply them much faster because it has already been sensitized by vaccination ${ }^{23}$.

\section{SARS-COV-2 vaccine}

The pandemic coronavirus seems to be a highly sophisticated evasion of pathogens caused by the failure of novel vaccines ${ }^{24}$. The spike proteins of the virus showed structural variability of the receptor domain was not clear ${ }^{25}$. Scientists faced a challenge in identifying the receptor-binding domain 26,27 . The whole-cell antigen method was then employed to identify the vaccine, but the viral strains of SARS-COV-2 did not show enough pathogenicity ${ }^{28}$. Then the N-terminal domain which has the S-protein was chosen as RBD, but it showed high variability with different epitopes that tend the virus to escape from the immune response ${ }^{29,30}$. The 2019$\mathrm{nCoV}$ causes an outgoing outbreak of lower respiratory tract disease called Novel coronavirus pneumonia (NCP) by the government initially ${ }^{31,32}$. This disease name was subsequently recommended as COVID-19 by the world health organisation $^{33}$. Meanwhile, 2019-nCoV was renamed SARS-COV-2 by the international committee on the Taxonomy of virus ${ }^{34}$.

\section{Techniques in vaccine preparation}

A vaccine created through the binhering of synbio-looks is not only scalable to a level of billions but also like it will work without the need for refrigeration ${ }^{35,36}$. Design and build nanoparticles out of protein and attach viral molecules in a repository array so that when the whole thing is patched into a vaccine it can make people resistant to the new coronavirus 37. Protein vaccine also known as the recombinant vaccine used to vaccinate against viral infections like HPV. These are simple to produce but need more time to develop ${ }^{38}$. Gene -based vaccine is the fastest way to make a vaccine, could be to have a person's own cells produce minute quantities of the viral protein that triggers an immune response ${ }^{38}$.

\section{Non-specific vaccine}

There is some evidence that the tuberculosis vaccine Bacillus-Calmette-Guerin (BCG) has non-specific beneficial effects against non-related infections ${ }^{39,40}$. Some studies claim that there is a correlation between the mortality of COVID-19 rate and BCG vaccine ${ }^{41}$. The amount of variance in case and deaths explained by BCG vaccination policy ranges between $12.5 \%$ and $38 \%$ by roughly dividing the countries into 3 categories showing a high, middle, or low growth rate of cases ${ }^{42,43}$. BCG which can remain alive in the human skin for several months triggers not only specific memory B and $\mathrm{T}$ cells but also stimulates the blood cells for a prolonged period.

\section{S-Protein based vaccine}

The S protein of SARS-COV, a type-1 transmembrane glycoprotein, responsible for virus binding fusion and entry and is a major inducer of neutralizing antibodies ${ }^{44}$. S-protein consists of a single peptide ${ }^{45}$. It targets the cell membrane into close proximity, which results in virus fusion and entry ${ }^{46}$. Several recombinant vector-based vaccines expressing SARS-COV S protein have been assessed in preclinical studies ${ }^{47,48}$. 


\section{CONCLUSION}

Though several vaccines against COVID 19 are under experimental trials, no effective vaccine has been released so far. All the countries across the globe are in the process of developing an effective vaccine to put an end to this rapidly spreading dreadful coronavirus disease. There is an increasing urge in the production of the vaccine for COVID infection. Many countries like the US, Russia, Australia, India, and other countries have successfully completed Phase-I and Phase-II trails and entered the human trail. In India the vaccine produced by Serum Institute of India the "Covi shield" and the one produced Bharat Biotech Ltd., the "Covaxin" have successfully entered the human trail. The Food and Drug Administration (FDA) has said that it was up to the vaccine developers to make the application for emergency use authorization, and if the application was found to be "appropriate", it may consider granting approval. From the scientific perspective, new technologies have been carried out in the development of a potential vaccine with unprecedented speed and take it to human trials in just a few months.

\section{ACKNOWLEDGEMENT}

We thank Saveetha dental college for the support to carry out this study.

\section{Conflict of Interest: Nil}

Funding Information: None

\section{REFERENCES}

1. Thanh Le T, Andreadakis Z, Kumar A, Gómez Román R, Tollefsen S, Saville M, et al. The COVID-19 vaccine development landscape.Nat Rev Drug Discov. 2020 May;19(5):305-6.

2. Glasman J. Mathematics of the Coronavirus Pandemic and Social Distancing.Treasure Trove of Math; $24 \mathrm{p}$.

3. Enjuanes L. Coronavirus Replication and Reverse Genetics. Springer Science \& Business Media; 2006.257 p.

4. Massironi S, Viganò C, Dioscoridi L, Filippi E, Pagliarulo M, Manfredi G, et al. Endoscopic findings in patients infected with 2019 novel coronavirus in lombardy, Italy. Clin Gastroenterol Hepatol [Internet]. 2020 May 29; Available from: http://dx.doi. org/10.1016/j.cgh.2020.05.045

5. Parikh S, Desai M, Parikh R. The Coronavirus: What you Need to Know about the Global Pandemic. Penguin Random House India Private Limited; 2020.224 p.

6. Roncati L, Ligabue G, Fabbiani L, Malagoli C, Gallo G, Lusenti B, et al. Type 3 hypersensitivity in COVID-19 vasculitis. ClinImmunol. 2020 May 29;108487.

7. Gupta N, Agrawal H. COVID 19 and laparoscopic surgeons, the Indian scenario - Perspective. Int J Surg [Internet]. 2020 May 29; Available from: http://dx.doi.org/10.1016/j.ijsu.2020.05.076

8. Gale RP. Conquest of COVID-19. Publish it to Death? Br J Haematol [Internet]. 2020 Jun 1; Available from: http://dx.doi. org/10.1111/bjh.16905

9. Ghafouri-Fard S, Noroozi R, Vafaee R, Branicki W, Posjpiech E, Pyrc K, et al. Effects of host genetic variations on response to, susceptibility and severity of respiratory infections. Biomed Pharmacother. 2020 May 29;128:110296.

10. Li W, Shi Z, Yu M, Ren W, Smith C, Epstein JH, et al. Bats are natural reservoirs of SARS-like coronaviruses. Science. 2005 Oct 28;310(5748):676-9.

11. Lu R, Zhao X, Li J, Niu P, Yang B, Wu H, et al. Genomic characterisation and epidemiology of 2019 novel coronavirus: implications for virus origins and receptor binding. Lancet. $2020 \mathrm{Feb}$ 22;395(10224):565-74.

12. Pan X, Chen D, Xia Y, Wu X, Li T, Ou X, et al. Asymptomatic cases in a family cluster with SARS-CoV-2 infection. Lancet Infect Dis. 2020 Apr;20(4):410-1.

13. Bai Y, Yao L, Wei T, Tian F, Jin D-Y, Chen L, et al. Presumed Asymptomatic Carrier Transmission of COVID-19. JAMA [Internet]. 2020 Feb 21; Available from: http://dx.doi.org/10.1001/ jama.2020.2565

14. Corman VM, Landt O, Kaiser M, Molenkamp R, Meijer A, Chu DKW, et al. Detection of 2019 novel coronavirus (2019-nCoV) by real-time RT-PCR [Internet]. Vol. 25, Eurosurveillance. 2020. Available from: http://dx.doi.org/10.2807/1560-7917. es.2020.25.3.2000045

15. Holshue ML, DeBolt C, Lindquist S, Lofy KH, Wiesman J, Bruce H, et al. First Case of 2019 Novel Coronavirus in the United States. N Engl J Med. 2020 Mar 5;382(10):929-36.

16. Li F. Structure, Function, and Evolution of Coronavirus Spike Proteins. Annu Rev Virol. 2016 Sep 29;3(1):237-61.

17. Shahana RY, Muralidharan NP. Efficacy of mouth rinse in maintaining oral health of patients attending orthodontic clinics [Internet]. Vol. 9, Research Journal of Pharmacy and Technology. 2016. p. 1991. Available from: http://dx.doi.org/10.5958/0974360x.2016.00406.6

18. Ashwin KS, Muralidharan NP. Vancomycin-resistant enterococcus (VRE) vs Methicillin-resistant Staphylococcus Aureus (MRSA). Indian J Med Microbiol. 2015 Feb;33 Suppl:166-7.

19. Girija ASS, Smiline Girija AS, Vijayashree Priyadharsini J, Paramasivam A. Plasmid-encoded resistance to trimethoprim/sulfamethoxazole mediated by dfrA1, dfrA5, sul1 and sul2 among Acinetobacter baumannii isolated from urine samples of patients with severe urinary tract infection [Internet]. Vol. 17, Journal of Global Antimicrobial Resistance. 2019. p. 145-6. Available from: http://dx.doi.org/10.1016/j.jgar.2019.04.001

20. Selvakumar R, NP M. Comparison in benefits of herbal mouthwashes with chlorhexidine mouthwash: A REVIEW [Internet]. Vol. 10, Asian Journal of Pharmaceutical and Clinical Research. 2017. p. 3. Available from: http://dx.doi.org/10.22159/ ajpcr.2017.v10i2.13304

21. Website [Internet]. [cited 2020 Jun 10]. Available from: Liu P, Chen W, Chen J-P. Viral Metagenomics Revealed Sendai Virus and Coronavirus Infection of Malayan Pangolins (). Viruses [Internet]. 2019 Oct 24;11(11). Available from: http://dx.doi. org/10.3390/v11110979

22. M MA, Geetha RV, Thangavelu L.Evaluation of anti-inflammatory action of Laurus nobilis-an in vitro studyf anti-inflammatory action of Laurus nobilis-an in vitro study [Internet]. Vol. 10, International Journal of Research in Pharmaceutical Sciences. 2019. p. 1209-13. Available from: http://dx.doi.org/10.26452/ ijrps.v10i2.408

23. Girija As S, Priyadharsini J V. CLSI based antibiogram profile and the detection of MDR and XDR strains of isolated from urine samples. Med J Islam Repub Iran. 2019 Feb 8;33:3.

24. Okba NM, Raj VS, Haagmans BL. Middle East respiratory syndrome coronavirus vaccines: current status and novel approaches. Curr OpinVirol. 2017 Apr;23:49-58.

25. Raj VS, Stalin Raj V, Okba NMA, Gutierrez-Alvarez J, Drabek D, van Dieren B, et al. Chimeric camel/human heavy-chain an- 
tibodies protect against MERS-CoV infection [Internet]. Vol. 4, Science Advances. 2018. p. eaas9667. Available from: http:// dx.doi.org/10.1126/sciadv.aas9667

26. Marickar RF, Geetha RV, Neelakantan P. Efficacy of Contemporary and Novel Intracanal Medicaments againstEnterococcus Faecalis [Internet]. Vol. 39, Journal of Clinical Pediatric Dentistry. 2014. p. 47-50. Available from: http://dx.doi.org/10.17796/ jcpd.39.1.wmw9768314h56666.

27. Widagdo W, Okba NMA, Stalin Raj V, Haagmans BL. MERScoronavirus: From discovery to intervention [Internet]. Vol. 3, One Health. 2017. p. 11-6. Available from: http://dx.doi. org/10.1016/j.onehlt.2016.12.001

28. Bosch BJ, Stalin Raj V, Haagmans BL. Spiking the MERScoronavirus receptor [Internet]. Vol. 23, Cell Research. 2013. p. 1069-70. Available from: http://dx.doi.org/10.1038/cr.2013.108

29. Vijay R. MERS Coronavirus: Methods and Protocols. Humana; $2019.224 \mathrm{p}$.

30. Sardesai NY, Weiner DB. Electroporation delivery of DNA vaccines: prospects for success. Curr Opin Immunol. 2011 Jun;23(3):421-9.

31. Pratha AA, Ashwatha Pratha A, Geetha RV. Awareness on Hepatitis-B vaccination among dental students-A Questionnaire Survey [Internet]. Vol. 10, Research Journal of Pharmacy and Technology. 2017. p. 1360. Available from: http://dx.doi. org/10.5958/0974-360x.2017.00240.2

32. Ugen KE, Sardesai N, Weiner DB. DNA vaccines 2010: A gumbo of accomplishment and excitement in New Orleans [Internet]. Vol. 29, Vaccine. 2011. p. 6721-2. Available from: http:// dx.doi.org/10.1016/j.vaccine.2011.07.026

33. Thalhamer J, Weiss R, Scheiblhofer S. Gene Vaccines. Springer Science \& Business Media; 2011.330 p.

34. Huang L, Liu D, Wagner E. Nonviral Vectors for Gene Therapy: Physical Methods and Medical Translation. Academic Press; 2015.271 p.

35. Girija SAS, Jayaseelan VP, Arumugam P. Prevalence of VIMand GIM-producing Acinetobacter baumannii from patients with severe urinary tract infection [Internet]. Vol. 65, Acta Microbiologica et Immunologica Hungarica. 2018. p. 539-50. Available from: http://dx.doi.org/10.1556/030.65.2018.038

36. Website [Internet]. [cited 2020 Jun 10]. Available from: Qi Z, Yu Y. Epidemiological Features of the 2019 Novel Coronavirus Outbreak in China [Internet]. Vol. 20, Current Topics in Medicinal Chemistry. 2020. Available from: http://dx.doi.org/10.2174/ 1568026620999200511094117

37. Smiline A, Vijayashree JP, Paramasivam A. Molecular characterization of plasmid-encoded blaTEM, blaSHV and blaCTX-M among extended spectrum $\beta$-lactamases [ESBLs] producing Acinetobacter baumannii. Br J Biomed Sci. 2018 Oct;75(4):200-2.

38. Paramasivam A, Vijayashree Priyadharsini J, Raghunandhakumar S. N6-adenosine methylation (m6A): a promising new molecular target in hypertension and cardiovascular diseases. Hypertens Res. 2020 Feb;43(2):153-4.

39. Priyadharsini JV, Vijayashree Priyadharsini J, Smiline Girija AS, Paramasivam A. In silico analysis of virulence genes in an emerging dental pathogen A. baumannii and related species [Internet]. Vol. 94, Archives of Oral Biology. 2018. p. 93-8. Available from: http://dx.doi.org/10.1016/j.archoralbio.2018.07.001

40. Lam TT-Y, Shum MH-H, Zhu H-C, Tong Y-G, Ni X-B, Liao $\mathrm{Y}-\mathrm{S}$, et al. Identification of 2019-nCoV related coronaviruses in Malayan pangolins in southern China [Internet]. Available from: http://dx.doi.org/10.1101/2020.02.13.945485

41. Lam TT-Y, Shum MH-H, Zhu H-C, Tong Y-G, Ni X-B, Liao Y-S, et al. Identifying SARS-CoV-2 related coronaviruses in Malayan pangolins [Internet]. Nature. 2020. Available from: http://dx.doi. org/10.1038/s41586-020-2169-0

42. Mph DIH, Hossain DI, MPH, National Institute of Preventive and Social Medicine (NIPSOM), Dhaka, Bangladesh. The Epidemiological Characteristics of an Outbreak of 2019 Novel Coronavirus Diseases (COVID-19) In Bangladesh: A Descriptive Study [Internet]. Vol. 08, Journal of Medical Science And clinical Research. 2020. Available from: http://dx.doi.org/10.18535/ jmscr/v8i4.94

43. Gao Q, Hu Y, Dai Z, Wu J, Xiao F, Wang J. The epidemiological characteristics of 2019 novel coronavirus diseases (COVID-19) in Jingmen, Hubei,China [Internet]. Available from: http:// dx.doi.org/10.1101/2020.03.07.20031393

44. He Y, Zhu Q, Liu S, Zhou Y, Yang B, Li J, et al. Identification of a critical neutralization determinant of severe acute respiratory syndrome (SARS)-associated coronavirus: importance for designing SARS vaccines. Virology. 2005 Mar 30;334(1):74-82.

45. Vaishali M, Geetha RV. Antibacterial activity of Orange peel oil on Streptococcus mutans and Enterococcus-An In-vitro study [Internet]. Vol. 11, Research Journal of Pharmacy and Technology. 2018. p. 513. Available from: http://dx.doi.org/10.5958/0974360x.2018.00094.x

46. Jiang S, Lin K, Strick N, Li YY, Neurath AR. Chemically modified bovine beta-lactoglobulin blocks uptake of HIV-1 by colonand cervix-derived epithelial cell lines. J Acquir Immune Defic Syndr Hum Retrovirol. 1996 Dec 15;13(5):461-2.

47. Priyadharsini JV, Vijayashree Priyadharsini J, Smiline Girija AS, Paramasivam A. An insight into the emergence of Acinetobacter baumannii as an oro-dental pathogen and its drug resistance gene profile - An in silico approach [Internet]. Vol. 4, Heliyon. 2018. p. e01051. Available from: http://dx.doi.org/10.1016/j. heliyon.2018.e01051

48. Sohaib Shahzan M, Smiline Girija AS, Vijayashree Priyadharsini J. A computational study targeting the mutated L321F of ERG11 gene in C. albicans, associated with fluconazole resistance with bioactive compounds from Acacianilotica. J Mycol Med. 2019 Dec;29(4):303-9. 